\title{
PELAKSANAAN KOMUNIKASI INTERPERSONAL ATAU KONSELING (KIP/K) OLEH BIDAN PADA ASUHAN ANTENATAL CARE
}

\author{
Listia Dwi Febriati ${ }^{1}$, Almira Gitta Novika ${ }^{2}$ \\ Universitas Respati Yogyakarta \\ (listiadwi@respati.ac.id)
}

\begin{abstract}
ABSTRAK
Latar Belakang: Konseling merupakan proses pemberian informasi kepada klien secara objektif dan lengkap. Pemberian layanan konseling perlu mempunyai panduan keterampilan konseling, teknik bimbingan dan penguasaan pengetahuan klinik (Saifuddin, 2010).Pelayanan kesehatan ibu hamil diwujudkan melalui pemberian pelayanan antenatal sekurang-kurangnya empat kali selama masa kehamilan, Standar waktu pelayanan tersebut dianjurkan untuk menjamin perlindungan terhadap ibu hamil atau berupa deteksi dini faktor risiko, pencegahan, dan penanganan dini komplikasi kehamilan (Kemenkes, 2014).

Tujuan: untuk mengetahui pelaksanaan komunikasi interpersonal atau konseling (KIP/K) oleh Bidan pada Asuhan Antenatal Care di PMB Mei Muhartati.

Metode: Penelitian ini merupakan penelitian kualitatif dengan pendekatan fenomenologi, teknik pengambilan sampel dengan menggunakan purposive sampling. Teknik pengumpulan data dengan menggunakan wawancara mendalam. Analisis data yang digunakan dalam penelitian ini adalah model interaktif Miles and Huberman yang terdiri dari 4 langkah yaitu pengumpulan data, reduksi data, penyajian dan analisis data berupa penarikan kesimpulan atau verifikasi data.

Hasil: Pelaksanaan Komunikasi Interpersonal atau Konseling oleh bidan pada pasien ANC yaitu sesuai dengan standar pelayanan kebidanan.

Kesimpulan: Pasien mendapatkan asuhan antenatal care sesuai dengan standar pelayanan kebidanan, temu wicara/ konseling yang diberikan mampu memberikan informasi dan pemahaman kepada pasien, meliputi keluhan makan, ketidaknyamanan, tanda bahaya, persiapan menyusui, persiapan persalinan.
\end{abstract}

Kata Kunci: Komunikasi Interpersonal Atau Konseling, Ibu Hamil, ANC 


\title{
The Implementation Of Midwife's Interpersonal Communication/Counseling On An Antenatal Care Practice
}

\begin{abstract}
Background: Counseling is a process of objectively and completely giving information to clients. A counseling service necessarily needs to posses counseling skill manuals, counseling techniques and clinical knowledge mastery (Saifuddin, 2010). Health cares for pregnant women are conducted through giving antenatal care at least four times during pregnancy period. The standard treatment time is given to guarantee protections for pregnant women or to detect early risk factors, prevention, and early pregnancy complication care (Ministry of Health, 2014).

The Aim: This research was aimed to find out the implementation of midwife's interpersonal communication/counseling on an antenatal care practice.

Method: This research was a quantitative research with phenomenological approach. The samples were obtained using purposive sampling. While, the data were collected through in-depth interviews and then analyzed using Miles and Huberman's interactive model which had four steps: data collection, data reduction, data analysis and presentation in the form of conclusions drawing and data verification.

Result: The implementation of midwife's interpersonal communication/counseling on an antenatal care patients agreed with the midwifery treatment standard.

Conclusion: The patients obtained antenatal care treatment which agreed with the midwifery treatment standard. The counseling given could provide information and understanding to the patients which were food complaints, discomfort, marks of danger, breast-feeding and childbirth preparation.
\end{abstract}

Keywords: interpersonal communication/counseling, pregnant women, ANC

\section{PENDAHULUAN}

Sebagai makhluk yang berpikir oleh karena itu, berbicara, komunikasi bagi manusia merupakan unsur yang tidak dapat dipisahkan dari kehidupannya. Komunikasi baginya adalah sarana untuk berinteraksi dengan "yang diluar dirinya". Saat pertama kali kita mendengar kata komunikasi, yang ada difikiran kita adalah berbicara dengan orang lain.Istilah komunikasi berasal dari bahasa latin Communicare atau Communis yang berarti sama atau menjadikan milik bersama. Kalau kita berkomunikasi dengan orang lain, berarti kita berusaha agar apa yang disampaikan kepada orang lain tersebut menjadi miliknya. Komunikasi sebagai kata benda (noun), communnication, berarti: Pertukaran simbol, pesanpesan yang sama dan informasi. Proses pertukaran antara individu melalui sistem simbol-simbol yang sama. Seni untuk mengekspresikan gagasan.Ilmu pengetahuan tentang pengiriman informasi (Casnuri dkk, 2020).

Konseling merupakan proses pemberian informasi kepada klien secara objektif dan lengkap. Pemberian layanan konseling perlu mempunyai panduan keterampilan konseling, teknik bimbingan dan penguasaan pengetahuan klinik 
(Saifuddin, 2010).Komunikasi interpersonal atau komunikasi antar pribadi adalahkomunikasi antara dua orang melalui kontak langsung dalam bentuk percakapan atau bisa disebut dengan komunikasi dialog. Penyampaian pesan dari seseorang kepada orang lain bersifat dua arah, secara verbal atau non verbal, misalnya antara bidan dengan kliennya. Komunikasi antar pribadi akan berhasil bila ada emphaty dan dukungan komunikasi, baik verbal maupun non verbal. Komunikasi interpersonal dibedakan menjadi dua yaitu komunkasi diadik dan komunikasi triadic (Handajani, 2016).

Peran strategis bidan dalam pencapaian SDGs tergambar melalui pemberian pelayanan kebidanan yang berkesinambungan dan paripurna, berfokus pada aspek pencegahan, promosi dengan berlandaskan kemitraan dan pemberdayaan masyarakat (Husin, 2013). Pelayanan kesehatan ibu hamil diwujudkan melalui pemberian pelayanan antenatal sekurang-kurangnya empat kali selama masa kehamilan, dengan distribusi waktu minimal satu kali trimester kesatu (usia kehamilan 0-12 minggu), satu kali trimester 2 (usia kehamilan 12-24 minggu), dua kali pada trimester ketiga (usia kehamilan 24 minggu sampai persalinan). Standar waktu pelayanan tersebut dianjurkan untuk menjamin perlindungan terhadap ibu hamil dan atau berupa deteksi dini factor risiko, pencegahan, dan penanganan dini komplikasi kehamilan (Kemenkes, 2014).

Data Kementerian Kesehatan menunjukkan angka kematian bayi dan ibu saat melahirkan mengalami penurunan sejak 2015 hingga semester pertama 2017. Berdasarkan data yang dikutip dari laman resmi Kementerian Kesehatan, Kamis (17/8) jumlah kasus kematian bayi turun dari 33.278 kasus pada 2015 menjadi 32.007 kasus pada 2016.Sementara hingga pertengahan tahun atau semester satu 2017 tercatat sebanyak 10.294 kasus kematian bayi. Demikian pula dengan angka kematian ibu saat melahirkan turun dari 4.999 kasus pada 2015 menjadi 4.912 kasus di tahun 2016. Sementara hingga semester satu di tahun 2017 terjadi 1.712 kasus kematian ibu saat proses persalinan (Aminah, 2017).

Pemerintah bersama masyarakat beranggung jawab untuk menjamin bahwa setiap ibu memiliki akses terhadap pelayanan kesehatan ibu yang berkualitas, mulai dari saat hamil, pertolongan persalinan oleh tenaga kesehatan terlatih dan perawatan pasca perslinan bagi ibu dan bayi (Infodatin, 2014).

Menurut Profil Kesehatan Indonesia (2016), Cakupan kunjungan K1 dan K4 di DIY dengan jumlah 59.512 ibu hamil yang melakukan kunjungan K1sebanyak 47.006 (78,99\%) dan kunjungan K4 sebanyak 43,519 (73.13\%). Berdasarkan data tersebut, cakupan kunjungan sudah di angka lebih dari 70\%.Jumlah ibu bersalin / nifas di DIY sebanyak 56.807 dengan kategori ibu bersalin di tolong oleh Nakes di Faskes sebanyak 42.934 (75.58\%).Kunjungan Nifas KF3 sebanyak 40.957 (72.10\%). Hal ini menunjukkan sudah cukup banyak ibu yang sadar akan pentingnya pertolongan persalinan oleh tenaga kesehatan.Berdasarkan studi pendahuluan yang dilakukan di BPM Mei Muhartati pada tanggal 19 Mei 2018 diperoleh rata- rata kunjungan ANC selama 1 Bulan adalah $30 \mathrm{ibu}$ hamil. Dengan harapan seorang ibu hamil yang melakukan kunjungan ANC di pelayanan kesehatan ibu mendapatkan informasi-informasi kaitannya dengan KIE (Komunikasi Informasi dan Edukasi) tentang kehamilan.Hal ini sesuai dengan penelitian yang dilakukan oleh Vionita (2014), 
bahwa terdapat hubungan yang signifikan antara dukungan tenaga kesehatan dengan frekuensi kunjungan ANC.

Berdasarkan latas belakang di atas, adapun rumusan masalah dalam penelitian iniadalah Bagaimana Pelaksanaan Komunikasi Interpersonal Atau Konseling $(\mathrm{Kip} / \mathrm{K})$ oleh Bidan Pada Asuhan Antenatal Care. Adapun tujuan penelitian ini adalah Evaluasi Keberhasilan Komunikasi Interpersonal Atau Konseling (Kip/K) oleh Bidan Pada Asuhan Antenatal Care

\section{METODE PENELITIAN}

Penelitian ini menggunakan pendekatan penelitian kualitatif dimana kualitatif sebagai metode ilmiah sering digunakan dan dilaksanakan oleh sekelompok peneliti dalam bidang ilmu social, termasuk juga ilmu pendidikan. Penelitian kualitatif dilaksanakan untuk membangun pengetahuan melalui pemahaman dan penemuan.Pendekatan penelitian kualitatif adalah suatu proses penelitian dan pemahamanyang berdasarkan pada metode yang menyelidiki suatu fenomena social danmasalah manusia. Pada penelitian ini peneliti membuat suatu gambarankompleks, meneliti kata-kata, laporan terinci dari pandagan responden danmelakukan studi pada situasi yang alami (Adi \& Wiryokusumo, 2016). Penelitian dilaksanakan di BPM Mei Muhartati, Sleman pada bulan September Oktober 2018.Informan dalam penelitian ini diambil dengan teknik purposive sampling yaitu seleksi partisipan, situasi atau unit waktu harus berorientasi pada tujuan penelitian atau berdasarkan kriteria yang sudah ditetapkan sangat umum digunakan pada riset fenomenologi.Pertimbangan tertentu yang dimaksud yaitu informan kunci dengan kriteria sebagai bidan pelaksana dan suami, sedangkan informan triagulasi adalah ibu yang melakukan kunjungan ANC di BPM Mei.Teknik pengumpulan data meliputi wawancara mendalam, Keabsahan data. Analisis data antara lain pengumpulan data, reduksi data, penyajian data, penarikan kesimpulan.

\section{Hasil}

\section{HASIL DAN PEMBAHASAN}

Tabel 1 Karakteristik responden berdasarkan

\begin{tabular}{lll}
\hline Kategori & $\begin{array}{l}\text { Frekuensi } \\
(\mathbf{f})\end{array}$ & $\begin{array}{l}\text { Persentase } \\
(\boldsymbol{\%})\end{array}$ \\
\hline Umur & 0 & 0 \\
$<20$ tahun & 0 & 100 \\
20-35 Tahun & 6 & 0 \\
$>35$ Tahun & 0 & 100 \\
Total & 6 & \\
Pendidikan & & 0 \\
SD & 0 & 16.67 \\
SMP/SLTA & 1 & 66.66 \\
SMA & 4 & 0 \\
Diploma & 0 & 16.67 \\
Sarjana & 1 & 100 \\
Total & 6 & \\
& &
\end{tabular}


Listia Dwi Febriati, Almira Gitta Novika (Pelaksanaan Komunikasi Interpersonal Atau Konseling (Kip/K) Oleh Bidan Pada Asuhan Antenatal Care)

\begin{tabular}{lll}
\hline Pekerjaan & 3 & \\
IRT & 2 & 50 \\
Swasta & 1 & 33.33 \\
Wiraswasta & 0 & 16.67 \\
Petani & 6 & 0 \\
Total & & 100 \\
& & \\
Pendapatan & 0 & 0 \\
< 1 juta & 2 & 33.33 \\
1 juta -2 juta & 4 & 66.67 \\
$>2$ Juta & 0 & 0 \\
Petani & 6 & 100 \\
Total & & \\
Gravida & & \\
Primi Gravida & 3 & 50 \\
Multi Gravida & 3 & 50 \\
Total & 6 & 100 \\
Trimester & & \\
TM I & & 0 \\
TM 2 & 0 & 0 \\
TM 3 & 0 & 100 \\
Total & 6 & \\
\hline
\end{tabular}

Tabel 2 Penjelasan Bidan pada saat ANC

\begin{tabular}{cl}
\hline Informan & \multicolumn{1}{c}{ Hasil } \\
\hline P1 & Hasil Pemeriksaan Fisik, Konseling keluhan, Pemberian Vitamin, \\
& Kapan Kunjungan Ulang \\
P2 & Hasil Pemeriksaan Fisik, Konseling keluhan, Pemberian Vitamin, \\
& Kapan Kunjungan Ulang, Rujukan ke pusskesmas \\
P3 & Konseling \\
P4 & Konseling \\
P5 & Hasil Pemeriksaan Fisik, Konseling \\
P6 & Konseling \\
\hline
\end{tabular}

..Dijelaskan mengenai detak janin, vitamin yang harus diminum, misalnya ada keluhan susah BAB, perut kembung (hasil wawancara P1)

......Periksa ya ... dijelasin BB, ditanyain keluhan, diukur TD, diperiksa perutnya, dijelaskan janin klo sdh ada detak jantungnya. Dijelaskan obat yang diminum setiap hari, setiap periksa seperti itu, yang buat dirujuk ke puskesmas itu juga ada. Untuk cek lab, iya kemarin sdh dilakukan, yang positif bakteri terus dikasih obat antibiotic. Saat UK masih 8 mgg. Itu saja sih, di cek HB juga bagus..normal..sama itu kayak psikolog itu dijelasin (hasil wawancara P2).

....Hmmmm banyak sih... kalo kayak aq kan perutnya suka kenceng, disuruh istirahat cukup (hasil wawancara P3).

......Soal ini apa......persalinan, punya jaminan apa, jaminan apa tu......bukan BPJS tapi jamkesmas, katanya nanti suruh diganti karena sudah diganti ke 
BPJS.Karena waktu TM 1 Suruh makan yang banyak,,, beratnya kurang (hasil wawancara P4).

Disini termasuk jelas ya buk, pertama tentang tensinya, panjang perut, ada pemeriksaan reflek di kaki baru nemu disini sebelumnya enggak. Pertama ditanya masalah puting karena sudah masuk Trimester 3. Awalnya nggak mau diperiksa, cuman dikasih tahu kalau puting saya mendatar dan diarahin untuk di keluarkan

pakai spuit. Saya langsung laksanakan dan 2 minggu setelah itu ASI keluar.

Puting yang 1 masih agak mendlep setiap malam saya bersihin puting pakai baby

oil. Disarankan juga makan banyak protein dan tempe. Saya ada keluhan kram sejak sebelum hamil. Sekarang juga sering mengalami kram dan sering kaku dan saya disarankan banyak jalan.(Hasil wawancara P5).

Sempat disuruh diet karena kakinya bengkak. Dijelaskan tentang pola tidur (hasil wawancara 06$)$.

Tabel 3 Alat Bantu Konseling

\begin{tabular}{cc}
\hline Informan & Hasil \\
\hline P1 & Buku KIA \\
P2 & Buku KIA \\
P3 & Buku KIA \\
P4 & Buku KIA \\
P5 & Buku KIA \\
P6 & Buku KIA \\
\hline
\end{tabular}

Disuruh membaca buku KIA....iya ini KIA....( Hasil wawancara P1)

Gak ada sih....KIAnya iya biasanya suruh membaca (Hasil wawancara P2)

Paling ini saja buku KIA aq jga baru 5 kali disini, BPJSnya disini baru pindah disini. (Hasil wawancara P3).

Iya Buku KIA...(Hasil wawancara P4)

Pada saat diberikan penjelasan tidak menggunakan buku KIA (hasil wawancara

P5).

Menggunakan buku KIA(hasil wawancara P6).

Tabel 4 Keluhan Makan

\begin{tabular}{cl}
\hline Informan & \multicolumn{1}{c}{ Hasil } \\
\hline P1 & Tidak bisa makan nasi \\
P2 & Tidak mau makan \\
P3 & Iya, gampang mabuk saat ke dapur \\
P4 & Tidak ada \\
P5 & Mual \\
P6 & Tidak Bisa makan nasi \\
\hline
\end{tabular}


Gak bias makan nasi,,,, Solusi: misalnya ga bisa makan nasi bisa diganti dengan ubi-ubian makanan yang berserat jangan banyak2 sehari bisa makan 4-5 kali Tindakan: Mencoba bisa melakukan yang diberikan bidan ( hasil wawancara P1).

Asam lambung Gak mau makan lemes...pas umur kehamilan 8 minggu..Solusi: Jangan terlalu banyak makan asam,,....kmrn juga beratnya turun harus dibalikin lagi beratnya...suruh minum susu...makan dikit-dikit tapi terus. Tindakan: Ya... tidak makan makanan yang asam, makan dikit2 tapi terus ( hasil wawancara P2).

Sekarang tidak ada dulu waktu hamil muda TM I mabuk ga ke dapur klo skg malah betah di dapur kebalik, hehehe.... kehamilan pertama g merasa apa2 tp kehamilan kedua ini teller banget. Solusi: katanya suruh makan makanan yang tidak menyengat atau berbumbu 2 tajam, kurangi santan, gorengan Tindakan: mau g mau dilawan sih mbak... hihi, paling kalau masak pake masker, bumbu2 diblender biar g bau, biasanya yg doyan pedes jd berkurang, awalnya aq ada kista jadi makanan g gorengan, jd keterusan, termasuk mi instan klo pas kepengan, bisa dihitung (Hasil wawancara P3).

Awal2 kehamilan mual2 bapaknya....saya tidak ada ...(Hasil wawancara P4).

Dari pas semenjak hamil ada keluhan mual di trimester 1 tapi sekarang sudah hilang. Saya tidak ada pantangan. Sekarang tidak ada keluhan pantangan. Sama bidan disuruh makan sayur dan buah karena berat bayi sudah 2,5 kg. Untuk makan siangnya disuruh makan nasi. Saya sudah melaksankan makan sayur dan

buah, kalau rasa laper muncul saya stop makan yang manis-manis(hasil wawancara P5).

Awalnya saya tidak suka nasi. Bidan pernah menyampaikan kalau nggak nasi bisa diganti dengan roti atau ubi-ubian dan saya sudah melakukan (hasil wawancara P6).

Tabel 5 Ketidaknyamanan

\begin{tabular}{ll}
\hline Informan & Hasil \\
\hline P1 & Keputihan, Susah BAB, Susah tidur, \\
& nyeri punggung \\
P2 & Nyeri Pinggang \\
P3 & Pegel, sering kencing \\
P4 & Pegel, Bengkak \\
P5 & Pantat linu, kaki kaku dan kram \\
P6 & Asma kambuh \\
\hline
\end{tabular}

Iya keputihan, Susah BAB, susah tidur, nyeri punggung.Solusi: kalau keputihan sih wajar, kalau yang susah BAB banyakin minum air putih, sama makan makanan yang berserat. Nyeri punggung banyakin minum air putih dan kompres air hangat, tiduran... istirahat yang cukup.Tindakan: dirumah melakukan saran dari bidan...(Hasil wawancara P1). 
Iya...klo sekarang sih pinganggannya nyeri. Solusi: mungkin kurang air putih, jalan-jalan pagi, senam hamil, ini kan umur sdh tua ya buk kepala janin semakin turun jadi disuruh untuk olahraga jalan2 biar langsung masuk gt lo.. Tindakan:

hehehe iya kalau jalan kadang2, klo senam hamil belum pernah hehehe..belum sempet sih..hehehe.. ...(Hasil wawancara P2).

Pegel, susah bergerak, tidur tidak nyaman, serba salah pokoknya, Sering kencing juga. solusi: hal itu wajar katanya bidan ...jadi tetep banyak minum ...dan kurangi minum berlebihan saat malam hari, jangan pakai sepatu atau sandal ber hak tinggi. Tindakan: ya paling klo tidur miring ke kiri, sama suami di elus 2 biar ga uring2ngan ...(Hasil wawancara P3).

Yang dikeluhkan punggung, sering kencing, pegel-pegel, Dulu bengkak klo ga ikut kerja ya g bengkak, Solusi: Kata bidannya cm kecapean biasa,,, Katanya biasa klo udah mau lahiran gpp. Tindakan: Cuma ini lho mbak istirahat...sebentar...terus ta kasih bantal...kakinya.. dipake tiduran enak,,,, (Hasil wawancara P4).

Kalau untuk di trimester 1 pernah mual dan saya sempat meriang dan mandi pakai air hangat siang dan sore. Pas masuk trimester 2 dibagian pantat aku linu banget dan waktu itu aku belum ikut senam hamil dan belum tahu info kehamilan dan biasanya hanya aku usap. Trimester 3 kaki sering kaku dan kram sehingga diminta banyak jalan dan rileks dan melakukan gerakan-gerakan sama minum air putih yang banyak. Kemarin sering merasa sesak dan disuruh mengatur nafas. Kalau badan lagi sehat sering jalan pagi dan rasanya beda.(hasil wawancara P5).

Ini baru asmanya sering kambuh. Lebih sering kambuh setelah kehamilan 8 bulan ini. Yang sudah dijelaskan bidan untuk menaikkan bantal saat tidur dan saya sudah mencoba dan keluhan berkurang (hasil wawancara P6).

Tabel 6 Keluhan Tanda Bahaya

\begin{tabular}{lll}
\hline Informan & Hasil \\
\hline P1 & Flek awal kehamilan & \\
P2 & Tidak ada & \\
P3 & Tidak ada & \\
P4 & Tidak ada & \\
P5 & Lemes dan pusing & \\
P6 & Nyeri perut bawah & \\
\hline
\end{tabular}

Keluhan : Bengkak baru beberapa hari ini....awal kehamilan sempet flek... saat UK 2 minggu.. karena sebelumnya belum terdeteksi... belum merasakan hamil gt.

Solusi : kata bidan suruh banyak istirahat waktu itu... Tindakan : ya banyak istirahat. Alhamdulilah tidak apa-apa (hasil wawancara P1).

Tidak ada sih buk... paling cma nyeri pinggang saja...soalnya nyuci baju jga jarang (hasil wawancara P2). 
Tidak ada,,paling perut kenceng saja...(hasil wawancara P3).

Gak ada......(hasil wawancara P4).

Kadang suka lemes dan pusing tapi aku pakai istirahat 1-2 jam pusingnya hilang. Saya belum pernah dijelaskan tentang tanda bahaya kehamilan tapi saya sering baca-baca dari buku (hasil wawancara P5).

Kalau pagi perut bagian bawah terasa nyeri. Bidan belum menjelaskan cara mengatasinya. Yang dilakukan ibu adalah nungging dengan inisiatif sendiri (hasil wawancara P6).

Tabel 7 Persiapan menyusui

\begin{tabular}{cc}
\hline Informan & Hasil \\
\hline P1 & Sudah \\
P2 & Sudah \\
P3 & Sudah \\
P4 & Sudah \\
P5 & Sudah \\
P6 & Belum dijelaskan \\
\hline
\end{tabular}

Sudah.........dibersihkan payudaranya setiap mandi dan setiap malam, melakukan pijatan ... pijataanya ya misalnya, putingnya dibersihin sambil dipijat-pijat. Biar ASI nya mulai keluar. Solusi: ya itu tadi. Tindakan: Melakukan pijat payudara tiap mandi dan setiap malam (hasil wawancara P1).

Sudah. Solusi: Diperiksa payudaranya putingnya dibersihin...sudah pernah sih cm apa waktu control sering dipegang diperiksa. Tindakan: Cuma dibersihin (hasil wawancara P2).

Sudah paham yang pertama juga sampai 2 tahun,paling dibersihin saja. Solusi: dibersihin dan dilakukan pijatan. Tindakan: Ya itu sering dibersihin saja. Dirumah sdh diterapkan (hasil wawancara P3).

Sudah tahu dan dijelaskan Solusi: Apa....hehehe....dibersihkan air hangat putting susunya...Sekarang Air susunya sudah keluar. Tindakan: setiap hari dibersihin dengan air hangat (hasil wawancara P4).

Untuk persiapan menyusui sudah dijelaskan oleh bidan (hasil wawancara P5).

Saya belum menyiapkan untuk menyusui nantinya dan belum pernah dijelaskan oleh bidan (hasil wawancara P6). 
Listia Dwi Febriati, Almira Gitta Novika(Pelaksanaan Komunikasi Interpersonal Atau Konseling (Kip/K) Oleh Bidan Pada Asuhan Antenatal Care)

Tabel 8 Persiapan persalinan

\begin{tabular}{ll}
\hline Informan & \multicolumn{1}{c}{ Hasil } \\
\hline P1 & Sudah \\
P2 & Sudah \\
P3 & Sudah \\
P4 & Sudah \\
P5 & Sudah dijelaskan tapi belum lengkap (perlengkapan bayi dan ibu) \\
P6 & Sudah dijelaskan tapi belum lengkap (perlengkapan bayi dan ibu) \\
\hline
\end{tabular}

Sudah....baju bayi popok dan sebagainya...untuk saya sendiri persiapan mental saja. Ya karena seperti itu sudah kodratnya sebagai wanita, 4 k sudah donor darah ayah... solusi: bidan memberitahu informasi tentang persiapan persalinan, keperluan bayi dan saya. Tindakan: membersihkan payudara dengan air anget (hasil wawancara P1).

Sudah....siap gak siap siap hehe. Solusi: Kemarin cuma ditanya perlengakapannya sudah belum? Saya jawab sudah, seperti donor belum diinfokan, transportasi belum, dananya iya kmrn ditanya kmrn untuk KIS BPJS disini bsa..iya saya pke KIS. Tindakan: mempersiapkan keperluan yang akan dibawa (hasil wawancara P2)

Sudah disiapkan. Soalnya pengalaman kehamilan anak pertama maju 3 mgguan, jadi sudah disiapkan ...hihi... P4K sudah dipersiapkan. Solusi: kemarin diinformasikan tentang persiapan bayi, persiapan ibu, dana, kendaraan dan donor darah. Tindakan: sudah kami siapkan semua (hasil wawancara P3)

Sudah, Solusi: Kemarin diberitahu untuk mempersiapkan keperluan bayi, ibu dana saat menjelang persalinan. Tindakan: sudah menyiapkan dan dimasukkan ke dalam tas...untuk barang-barang kebutuhan saya dan bayi (hasil wawancara

Untuk persiapan baju bayi dan ibu sudah disiapkan. Untuk jaminan kesehatan juga sudah. Tapi karena saya pakai BPJS dari pemerintah bukan mandiri nggak bisa dibukain BPJS untuk bayinya sekarang. Selain itu belum dijelaskan persiapan yang lain apalagi (hasil wawancara P5)

Cuma baju-baju bayi, baju saya dan kartu BPJS. Belum pernah dijelaskan oleh bidan apa saja yang dipersiapkan menjelang persalinan (hasil wawancara P6).

Tabel 9 Langkah-langkah konseling

\begin{tabular}{|c|c|c|c|c|c|c|}
\hline \multirow[t]{2}{*}{ Langkah } & \multicolumn{6}{|c|}{ Hasil } \\
\hline & P1 & $\mathbf{P 2}$ & P3 & P4 & P5 & P6 \\
\hline SIKAP & & & & & & \\
\hline $\begin{array}{l}\text { Menyambut dan memperkenalkan diri kepada klien dan keluarga } \\
\text { dengan sopan dan ramah }\end{array}$ & tdk & tdk & tdk & tdk & tdk & tdk \\
\hline $\begin{array}{l}\text { Menjelaskan prosedur dan tujuan tindakan yaang akan } \\
\text { dilakukan }\end{array}$ & Ya & Ya & Ya & Ya & Ya & Ya \\
\hline Merespon reaksi klien dengan tepat dan kontak mata & Ya & Ya & Ya & Ya & Ya & Ya \\
\hline
\end{tabular}




\begin{tabular}{|c|c|c|c|c|c|c|}
\hline \multicolumn{7}{|l|}{ ISI } \\
\hline Menanyakan keluhan yang dirasakan klien & Ya & Ya & Ya & Ya & Ya & Ya \\
\hline Mengklarifikasinya dan menggali keluhan yang dirasakan klien & Ya & Ya & Ya & Ya & Ya & Ya \\
\hline $\begin{array}{l}\text { Menggali perasaan/pengalaman klien berkaitan dengan masalah } \\
\text { kehamilan yang dihadapi }\end{array}$ & Ya & Ya & Ya & Ya & tdk & Ya \\
\hline Mengulang pernyataan klien berkaitan dengan permasalahannya & Ya & Ya & Ya & Ya & Ya & Ya \\
\hline $\begin{array}{l}\text { Melakukan apersepsi kepada klien berkaitan dengan keluhan } \\
\text { yang dialami }\end{array}$ & tdk & tdk & tdk & tdk & tdk & tdk \\
\hline Menjelaskan tentang materi konseling sesuai dengan kebutuhan & Ya & Ya & Ya & Ya & ya & Ya \\
\hline Memberikan kesempatan bertanya kepada klien & Ya & Ya & Ya & Ya & ya & Ya \\
\hline $\begin{array}{l}\text { Mengevaluasi pemahaman klien berkaitan dengan materi } \\
\text { konseling yang telah diberikan }\end{array}$ & Ya & Ya & $\mathbf{Y a}$ & Ya & ya & Ya \\
\hline Menyimpulkan hasil konseling yang telah dilaksanakan & Ya & Ya & Ya & Ya & ya & Ya \\
\hline Membuat kesepakatan untuk kunjungan ulang & Ya & Ya & Ya & Ya & ya & Ya \\
\hline \multicolumn{7}{|l|}{ TEKNIK } \\
\hline Melaksanakan tindakan dengan percaya diri dan tidak ragu-ragu & Ya & Ya & Ya & Ya & ya & Ya \\
\hline Melaksanakan tindakan dengan bahasa yang mudah dimengerti & $\mathbf{Y a}$ & Ya & Ya & Ya & ya & ya \\
\hline Menjaga privasi klien & Ya & Ya & Ya & Ya & ya & Ya \\
\hline
\end{tabular}

........Biasanya menunnggu, masuk ditanya keluhannnya apa, kemudian cara mengatasinya, periksa $B B$, pemeriksaan payudara.

.......Ekspresi selalu sopan ramah, empati.

.........Bidan selalu ijin akan melakukan tindakan....termasuk ijin melakukan tindakan...

..Memberikan evaluasi dengan digali oleh bu bidan Kaloo udah paham ya udah... klo belum ya dijelaskan lagi...

Bidan menggunakan bahasa yang mudah dimengerti, ruangan selalu tertutup. Terus dijelaskan kapan kunjungan ulang, dikasih obat juga (hasil wawancara P1).

....Klo datang antri, nanti baru disuruh masuk, terus nanti ditanya keluhannya ditimbang BBnya terus ditensi suruh tiduran begitu terus sama diperiksa payudara, gigi juga biasanya, periksanya sampai kaki, sama diperiksa perut detakjantungnya juga. Kakinya juga di ketuk...ini pas apa ya...dengkul...hehe...terus abis itu sudah. Biasanya ditanya obatnya masih? kalo masih ya tdk dikasih tapi kalo habis dikasih lahi. Terus dijelasin sama kembalinya kapan. ....Perkenalan diri gak ada sih...krna sdh kenal... ....Tujuan prosedur ada sih nanti seperti " nanti diperiksa perut...dianjurkan USG...maaf ya saya buka ...misalnya bgtu..." ....Bidan juga menggali keluhan saya . ....Bertanya kembali ada, tapi saya jarang Tanya.hehehe... ....Terus sdh cukup langsung pulang ....Kesepakatanya.... control selanjutnya missal 2 minggu balik kesini lagi ....Istilah medis kayaknya gak sih ...bahasa mudah dipahami ....Privasi iya yang mungkin yg ikut Cuma anaknya dan suami yang masuk. ....Kesimpulan biasanya ada,,, missal diakhir dipeseni jangan lupa ya buk "banyakin air putihhh banyakin istirahat bgtu". (hasil wawancara P2). 
....Enggak memperkenalkan diri ....Tujuan prosedur...iya... ....Ekspresi iya makanya aq lanjut disini, daripada di rumah sakit, disini lebih care ....Menggali keluhan iya, ....Menjelaskan materi sesuai kebutuhan .... Sering bertanya, ....Diklarifikasi lagi

Dikasih kesempatan untuk bertanya juga. ....Disimpulkan yak lo ada yang ditanyakan ya di jelaskan ....Percaya diri tidak ragu ....Bahasa mudah dipahami ....Pintu tetep ditutup

....Dijelaskan kapan kunjungan ulang dan diberi obat (hasil wawancara P3).

....Prosedur dan tujuan iya...nggih... ....Kontak mata iyaaa .....Menggali: iya ....Menjelaskan materi sesuai kebutuhan: iya ....Diberi kesempatan untuk Bertanya : nggih... ....Menanyakan kembali: tidak ....Kunjungan ulang : iyak...iya .... Obatnya tadi tidak dikasih Kan baru 1 minggu jadi obatnya masih. ....Diingatkan juga kapan kunjungan ulang. .....Bahasa mudah dimengerti. .....Pintu selalu ditutup (hasil wawancara P4).

Pas datang saya disapa, ditanya keluhan. Bidan diawal tidak memperkenalkan diri. Setiap mau melakukan tindakan bidan belum menjelaskan tindakan apa saja yang akan dilakukan untuk pasien. Kalau pada saat pemeriksaan saya merasa kenceng bidan merespon keluhan saya. Apa yang saya tanya langsung ditanggapi. Keluhan yang saya sampaikan tidak dikaji lebih dalam oleh bidan. Apa yang dijelaskan bidan sudah sesuai dengan kebutuhan saya. Bidan biasanya memberi saya kesempatan untuk bertanya. Di akhir tidak dilakukan evaluasi dan disimpulkan oleh bidan. Disepakati kunjungan berikutnya oleh bidan. Bidan menggunakan bahasa yang mudah saya pahami (hasil wawancara P5).

Bidan menyampaikan kakinya bengkak terus menyuruh kalau tidur disuruh kaki dinaikkan. Bidan menyambut tetapi tidak memperkenalkan karena sudah kenal dengan saudara yang mengantar. Saya tidak diberitahu akan dijelaskan tentang apa saja di awal. Pada saat ditanya keluhan, keluhan saya ditanya lebih dalam oleh bidan. Tetapi saya tidak ditanya saya cemas atau tidak. Penjelasan bidan sudah bermanfaat untuk saya. Bidan memberi kesempatan pada saya untuk bertanya. Diakhir bidan juga mengevaluasi dari apa yang sudah dijelaskan dan disimpulkan. Bidan menyepakati kunjungan berikutnya. Bidan menggunakan bahasa yang mudah dipahami (hasil wawancara P6). 


\section{Pembahasan}

Komunikasi interpersonal adalah interaksi yang dilakukan dari orang ke orang, bersifat 2 arah baik verbal maupun non verbal, dengan saling berbagi informasi dan perasaan antara individu dgn individu atau antar individu dalam kelompok kecil. Konseling adalah proses pemberian informasi obyektif dan lengkap, dilakukan secara sistematik dengan panduan komunikasi interpersonal, teknik bimbingan dan penguasaan pengetahuan klinik, bertujuan untuk membantu seseorang mengenali kondisinya saat ini, masalah yang sedang dihadapi dan menemukan jalan keluar atau upaya mengatasi masalah tersebut (Estiwidani, 2010).

Pada awal pertemuan bidan telah memperkenalkan diri pada pasien.Memperkenalkan diri anda sebagai konselor dan meminta klien memperkenalkan diri serta menyepakati bahasa apa yang akan digunakan. Mendapatkan informasi umum tentang klien Jelaskan peranan dan tanggung jawab kamu sebagai konselor: mendengarkan, memberikan dukungan, membantu mereka mengidentifikasikan masalah dan solusi yang memungkinkan. Namun seiring dengan waktu kunjungan yang rutin, bidan dan pasien sudah sangat akrab dan hafal pasien- pasien yang berkunjung dibidan tersebut sehingga langkah perkenalan saat konseling sering tidak dilakukan. Karena dirasa jika hal tersebut dilakukan terus terkesan resmi dan bidan malah tidak care dengan pasiennya.

Pada saat memberikan konseling kepada ibu hamil bidan telah menumbuhkan rasa empati dengan cara menggali keluhan dan memberikan konseling sesuai dengan keluhannya. Hal ini sesuai dengan standar $10 \mathrm{~T}$ Antenatal Care yang salah satunya adalah tatalaksana kasus sesuai dengan kebutuhan pasien. Pada saat konseling bidan menggunakan alat bantu buku KIA. Manfaat media ini adalah untuk menimbulkan minat, mengatasi hambatan bahasa, mempermudah penerimaan informasi oleh sasaran yang pada akhirnya akan merangsang sasaran untuk melaksanakan pesan-pesan kesehatan (Notoatmodjo, 2012).

Ibu hamil sering mengalami keluhan mual dan muntah serta tidak nafsu makan.Dalam hal ini bidan memberikan konseling bahwa ibu dianjurkan makan sedikit demi sedikit tetapi sering serta menghindari makanan yang berminyak dan berbumbu keras (Dewi, 2011). Pada dasarnya setiap individu menghadapi permasalahan, diantara masalah individu tersebut, beberapa masalah dapat dipecahkan sendiri tanpa bantuan konselor sedangkan masalah lainnya masih belum bisa diselesaikan sehingga membutuhkan konselor. Pada umumnya masalah emosi konseli (klien) yang cara penyelesaiannya membutuhkan bantuan konseling antara lain adalah kecemasan (Hartono dan Boy, 2012).

Ibu hamil wajar mengalami ketidaknyamanan fisiologis dalam kehamilan seperti sering buang air besar, mual muntah, keputihan, sakit kepala.Bidan telah memberikan konseling kepada ibu hamil sesuai dengan ketidaknyamanan yang dialami.Tanda bahaya dalam kehamilan meliputi perdarahan pervaginam, sakit kepala yang hebat, gerakan janin berkurang, nyeri perut yang hebat, bengkak pada muka dan tangan, muntah yang terus menerus, perubahan penglihatan, kejang, demam dan ketuban pecah dini. Bidan memberikan konseling tentang tanda bahaya kehamilan kepada ibu hamil sehingga ibu dapat mengenali apabila mengalami salah satu dari tanda bahaya tersebut. Menurut Heru dkk (2012), 
pelaksanaan konseling yang dilakukan di BPS maupun di Puskesmas sudah cukup membantu ibu hamil dalam memahami perubahan yang terjadi selama kehamilan dan kebutuhan dirinya.

Untuk mempersiapkan menyusui setelah ibu melahirkan, bidan hendaknya mengajarkan bagaimana perawatan payudara sejak kehamilan ibu yaitu dengan melihat apakah putting susu ibu menonjol atau masih masuk ke dalam dan membersihkan payudara menggunakan baby oil. Bidan hendaknya juga memberikan konseling tentang persiapan persalinan. Persiapan persalinan yang perlu dipersiapkan oleh ibu antara lain perlengkapan ibu dan bayi, transportasi, biaya, donor darah, pendamping dan penolong persalinan.

Dalam pemberian konseling hendaknya bidan melaksanakannya sesuai dengan prosedur.Dalam penelitian ini bidan tidak memperkenalkan diri di awal pertemuan dan tidak melakukan apersepsi kepada klien berkaitan dengan keluhan yang dialami.Diawal sebelum bidan memberikan konseling kepada ibu hamil salah satu langkah yang seharusnya dilakukan oleh bidan adalah memperkenalkan diri.Dengan memperkenalkan diri dapat membina hubungan saling percaya antara pasien dengan bidan.

\section{SIMPULAN DAN SARAN}

\section{Simpulan}

Pasien mendapatkan asuhan antenatal care sesuai dengan standar pelayanan kebidanan, temu wicara/ konseling yang diberikan mampu memberikan informasi dan pemahaman kepada pasien, meliputi keluhan makan, ketidaknyamanan, tanda bahaya, persiapan menyusui, persiapan persalinan.

Saran

Meningkatkan upaya pemberian konseling dengan tetap mempertahankan efektifitas konseling yang meliputi Keterbukaan (openess), Empati (empathy), Dukungan (supportiveness), Rasa positif (positiveness), Kesetaraan (equality). Menambah alat bantu yang bias digunakan pada saat konseling yaitu penggunaan poster atau leaflet pada saat konseling

\section{DAFTAR PUSTAKA}

Abdul Bari Saifuddin. 2010. Ilmu Kebidanan, Edisi 4. Jakarta: Bina Pustaka Sarwono Prawirohardjo.

Adi, Djoko.,\& Wiryokusumo, Iskandar. 2016. Metode Penelitian Kualitatif. Surabaya: Universiti Press

Aminah, AN.2017. Kemenkes Sebut Angka Kematian Bayi dan Ibu Melahirkan

Turun.

http://nasional.republika.co.id/berita/nasional/umum/17/08/17/ouu4ox384-

kemenkes-sebut-angka-kematian-bayi-dan-ibu-melahirkan-turun. Diakses tanggal 21 Februari 2018.

Casnuri, Fauziah A, Febriati L D. 2020. KOmunikasi KOnseling Bagi Mahasiswa Dan Tenaga Kesehatan. Yogyakarta: Respati Press.

Estiwidani.2010. Pelayanan Keluarga Berencana. Fitramaya. Yogyakarta. 
Handajani, Sih Rini. 2016. Modul Bahan Ajar Cetak Kebidanan Komunikasi Dalam Praktik Kebidanan.Kementerian Kesehatan Republik Indonesia. Pusat Pendidikan Sumber Daya Manusia Kesehatan Badan Pengembangan Dan Pemberdayaan Sumber Daya Manusia Kesehatan.

Hartono dan Boy. 2012.Psikologi Konseling Edisi Revisi.Jakarta:Kencana.

Heru, Retno., Hasanbasri, Mubasysyir., Hakimi, Mohammad. 2012. Konseling Ibu Hamil Pada Bidan Praktik Swata dan Puskesmas Di Kabupaten Bantul.Jurnal Kebijakan Kesehatan Indonesia. Volume 01 No.03 September 2012.

Husin, Farid. 2013. Asuhan Kebidanan Berbasis Bukti. Sagung Seto. Jakarta.

INFODATIN. $2014 . \quad$ Mother's Day. http://www.depkes.go.id/resources/download/pusdatin/infodatin/infodatinibu.pdf. Diakses tanggal 21 Februari 2018.

Kemenkes RI. Profil Kesehatan Indonesia Tahun 2014. Jakarta: Kemenkes RI; 2015

Lia, Dewi, Nanny Vivian dan Tri Sunarsih. 2011. Asuhan Kehamilan Untuk Kebidanan. Jakarta: Salemba Medika.

Notoatmodjo, Soekidjo. 2012. Pendidikan dan perilaku kesehatan. Jakarta: Rineka Cipta

Vionita .2014.Faktor-Faktor yang berhubungan dengan frekuensi kunjungan ANC di Puskesmas Mergangsan DIY. Jurnal Medika Respati. Vol. 12 Nomor 1 Januari 2017. ISSN: 1907-3887 